\title{
Prevalence of Oesophageal cancers and Diagnosis
}

\author{
Dr. K. Ravi ${ }^{1}$ M.S Ent, Dr. A. Kavitha ${ }^{2}$ M.D. D.M. \\ $\left({ }^{1}\right.$ Tutor in Gastro Enterology Department 2. Professo of Gastro Enterology Department, Guntur Medical \\ College, Guntur)
}

\begin{abstract}
The incidence of oesophageal cancers rising in the society due to rapid urbanization, increased tobacco smoking, consumption of tobacco leaves, betel nut, panparag,jarda chewing, alchol consumption, and another important factor is Iron deficiency anaemia due to nutritional imbalance and the incidence is more in females, and highly prevalent in low socioeconomic condition. Here are the cases of Dysphagia reported in The Department of Gastroenterology, Guntur Medical college, Guntur, among which the esophageal cancer though stands less in the census made in 2009-2014 makes hihest mortality than other cases .
\end{abstract}

Keywords: Dysphagia, Esophageal cancer; Endoscopic findings Materials \& Methods

\section{Introduction}

Oesophageal cancer is a tumour that begins to grow in the lining of the oesophagus and then can grow through the wall of the oesophagus. If the tumour grows through the oesophageal wall, it can then spread to other parts of the body through the lymphatic system.

Most of the length of the oesophagus is lined with squamous cells. If a malignant tumour grows here, it's called squamous cell carcinoma. The areas at the bottom of the oesophagus, and where the oesophagus joins the stomach, are lined with columnar cells. If a malignant tumour grows here, it's called adenocarcinomas.

Studies have shown a relationship between frequency of reflux symptoms and risk of adenocarcinoma. The constant acid reflux will irritate the lining of the oesophagus, and complications can occur, such as Barrett's oesophagus. Individuals who develop Barrett's oesophagus are about 40 times more likely to develop oesophageal cancer than individuals in the general population.

\section{Symptoms of oesophageal cancer}

Difficulty swallowing

Inability to swallow solid foods (eventually liquids also)

Pain with swallowing

Food sticking in oesophagus

Weight loss, Vomiting blood

Diagnosis:

Endoscopy

Barium x-rays

\section{Materials and methods;}

Total no of Out patients visiting Gastro Department GGH,Guntur Medical college recorded From 2009-2014 are 15,000

Total no dysphagia cases recorded during that period

$$
6,000
$$

Total no of Oesophageal cancers noted in that period $\quad 400$

No of post cricoids web cases recorded $\quad 1,200$

No of Acid ingestion cases reported 100

No. Of GERD cases reported $\quad 800$

No of Minilial esophagitis noted $\quad 1,000$

\begin{tabular}{|l|l|l|l|l|l|l|l|}
\hline $\begin{array}{l}\text { Total no of } \\
\text { pts. Visited } \\
\text { in GE dept } \\
\text { 2009-14 as } \\
\text { OPD }\end{array}$ & $\begin{array}{l}\text { Total No of } \\
\text { Pts with } \\
\text { dysphagia }\end{array}$ & $\begin{array}{l}\text { Total no notal no of } \\
\text { pts with } \\
\text { GERD }\end{array}$ & $\begin{array}{l}\text { Total } \\
\text { pts wonith } \\
\text { Monhagitis } \\
\text { esophagith }\end{array}$ & $\begin{array}{l}\text { Total no pts } \\
\text { with acid } \\
\text { ingetion }\end{array}$ & $\begin{array}{l}\text { Total no pts } \\
\text { with ca } \\
\text { oesophagus }\end{array}$ & $\begin{array}{l}\text { Total no of } \\
\text { pts with PC } \\
\text { web }\end{array}$ & $\begin{array}{l}\text { Total no of } \\
\text { pts Normal } \\
\text { study }\end{array}$ \\
\hline 15000 & 6000 & 800 & 1000 & 100 & 400 & 1200 & 2500 \\
\hline
\end{tabular}




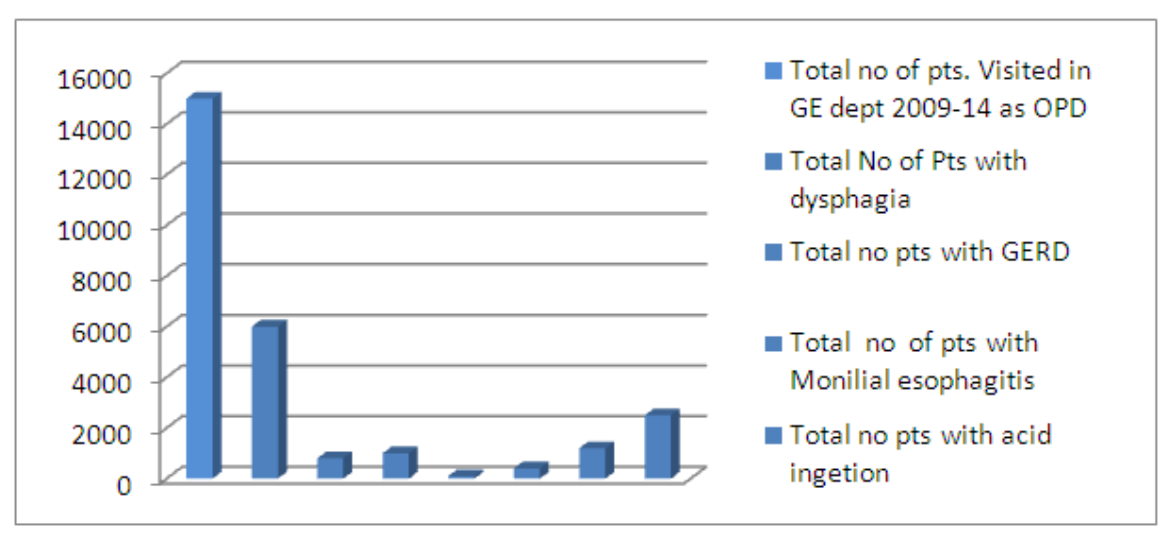

\section{Treatment}

Treatment of oesophageal cancer will depend on the stage of the cancer. and whether the cancer has spread to other organs.If the cancer has not spread to other organs, surgery may be performed to remove the portion of the oesophagus. Then another part of the lower bowel is pulled up and attached to the remaining section of oesophagus. Patients may receive chemotherapy and radiotherapy treatments after the surgery.If the cancer has spread to other organs in the cases where the patient can't have surgery., combined chemotherapy and radiotherapy is the most common treatment. For squamous cell carcinoma Radio therapy treatment of the choice. For Adenocarcinoma -Surgery followed by chemotherapy is the treatment.

\section{Conclusion}

Oesophageal cancers contribute $5-10 \%$ of all dysphagia cases reported in the period of 5 yrs from 2009-2014. Most of the cases by the time come to opd they are in advanced stage, and for them when we do gastroscopy as screening and diagnostically most of the cases found to have advance $\mathrm{d}$ Ulceroproliferative growths either partially, or completely obstructing the lumen, and taken biopsy for histopathalogical examination which reveals either sqamous cell carcinoma,or adeno carcinoma depends on the site of the tumor., and these cases once confirmed as malignancy we refer them to either RT department or if the tumor is in early stage, involving only oesophagus referring to General Surgery Department for EsophagoGastrectomy. And we made follow up for $5 \mathrm{yrs}$, Most of these cases showed highest mortality due to spread of the tumor to distant sites involving brain,liver,lungs , and those cases survived after Radiotherapy and surgery reviewed to Gastro op for Gastroscopy which revelas that ,there is regression of tumour noted., however shows narrowing and Radiation induced strictures of the esophagus .For these cases CRE balloon dilatation done to open the lumen for passage of the food..

If the cancer is diagnosed in its earliest stages, the patient's chances of living and be cancer free five years after treatment is greatly improved. Unfortunately, most cases of oesophageal cancer is only discovered when the patient comes to their doctor because of swallowing difficulty, which doesn't happen until later stages of the cancer growth. The prognosis then is very poor.

\section{Sites of oesophageal cancer}

\begin{tabular}{|c|c|c|c|}
\hline Sr.No. & No of pts with Growth at PC area & $\begin{array}{llll}\begin{array}{l}\text { Growth at } \\
\text { esophagus }\end{array} & \text { Middle } & 3^{\text {rd }} & \text { of } \\
\end{array}$ & Growth at GE junction \\
\hline 1 & $25 \%$ & $15 \%$ & $10 \%$ \\
\hline
\end{tabular}




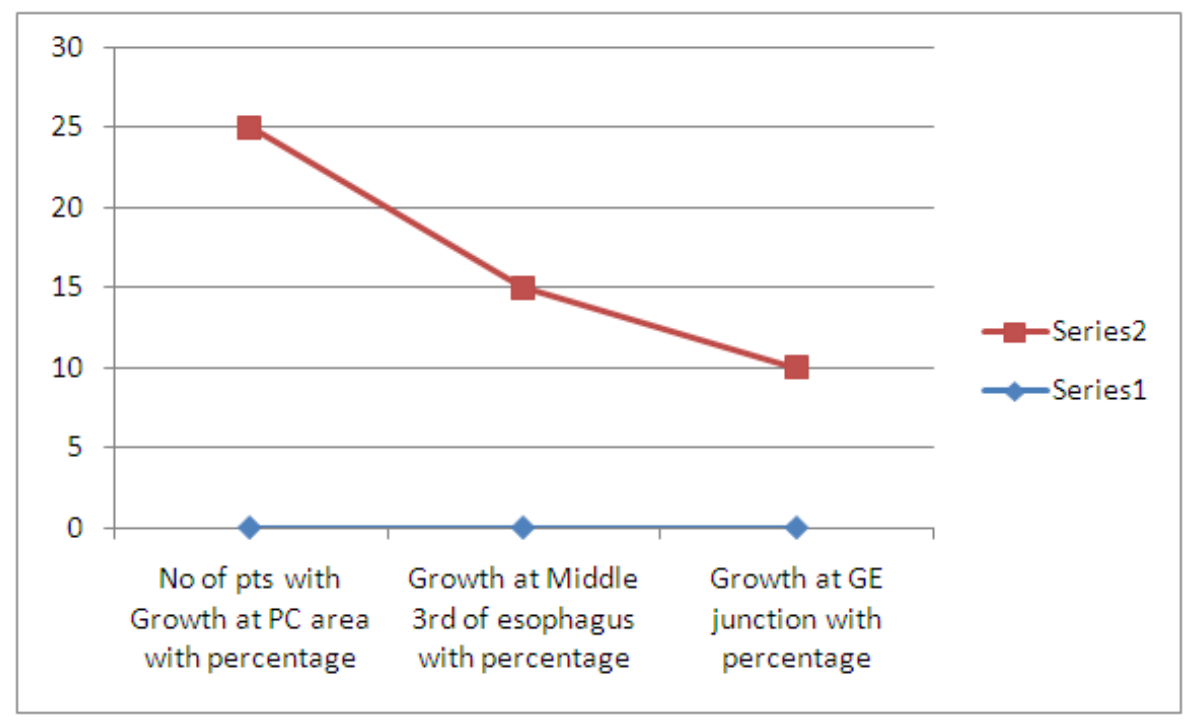

Ca esophagus growth at PC area

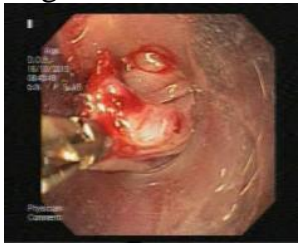

Ca Esophagus Growth at middle 3rd

CRE balloon dilatation
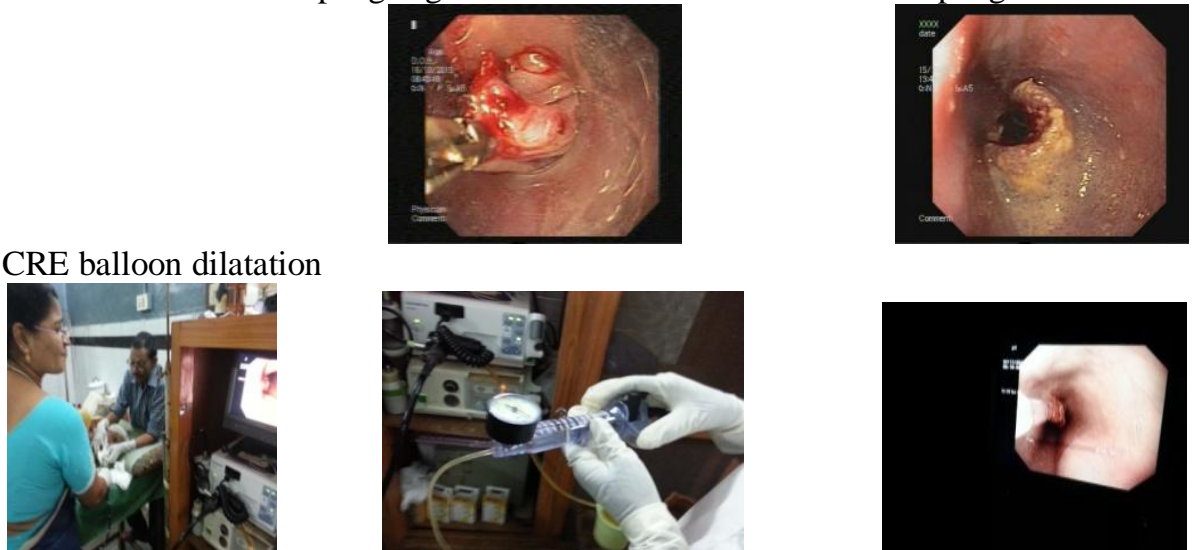

CRE Balloon dilation to pt with Post Radiotherapy of pt Ca esophagus 